\title{
Short Communication: Proportion faunal assemblages of carnivorous mammals in geoecological districts of Mordovia, Russia
}

\author{
ALEXEY ANDREYCHEV \\ Department of Zoology, National Research Mordovia State University. Bolshevistskaya street, 68, Saransk 430005, Russia. Tel./fax.: +7-342-322637, \\ •email: teriomordovia@bk.ru
}

Manuscript received: 7 August 2021. Revision accepted: 29 September 2021.

\begin{abstract}
Andreychev A. 2021. Short Communication: Proportion faunal assemblages of carnivorous mammals in geoecological districts of Mordovia, Russia. Biodiversitas 22: 4625-4632. In the forest-steppe area, carnivorous mammals are represented by species of different faunistic assemblages. This circumstance makes the study region a priority since the species of which faunistic assemblages prevail is of interest. Fifteen carnivorous species have been identified in the territory of Mordovia. Among them, the family Mustelidae predominates in terms of the number of species. The species are found in all geoecological districts, but their distribution is uneven. The most notable species in the region are located in coniferous and broad-leaved forests (40\%) and species widely distributed in several natural areas (40\%). 13\% of the total number of noted species belong to the taiga fauna types. The steppe type of fauna is represented by only $7 \%$ of the total number of recorded species. For each geoecological region, the fauna features are given, and a list of rare and exciting species is given. The forest-steppe zone to which Mordovia belongs is compared by the fauna of carnivorous mammals with other regions from three typical faunal assemblages.
\end{abstract}

Keywords: Assemblage, carnivorous, habitat, Russia, species

\section{INTRODUCTION}

The study of predators is important to understand competition among predators and predator-prey relationships so that the viable populations of predators and herbivorous, insectivorous mammals can be sustained (Charaspet et al. 2021). The number of predator species also affects their competitive activity (Lucherini et al. 2009). The abundance and species composition of carnivorous depend highly on the landscape zone. Therefore, we adhere to the term faunal assemblage (Stroud et al. 2015). The definition of assemblage should be used, which will display the following «a taxonomically close group of species that co-occur in time and space» (Stroud et al. 2015). Over the past ten years in Russia, there have been very few zoogeographic papers on mammals, including carnivores.

In Mordovia, studies of mammalian fauna are associated with the period of expedition research of academician Peter Simon Pallas in 1768-1774. In the initial review work on birds and mammals of the middle and lower Volga valley, Bogdanov (1871) gave the first mention of 35 species of mammals from the modern territory of Mordovia. Before forming the Mordovian Autonomous region, data on some new mammal species for this region were reported for the territories of four provinces: Tambov, Nizhny Novgorod, Penza, and Simbirsk, some of which were part of modern Mordovia. Subsequently, the mammal fauna of the region was updated with information about new species (Andreychev and Kuznetsov 2012).

In this article, we present new information on the carnivorous fauna of the Mordovia and identify these species' distribution along the geoecological regions in the study area. Over time, many species have become rare due to competition with newly introduced species. Human activities played an important role. Many hunters have stopped hunting for some species (Mustela putorius, M. nivalis, $M$. erminea) of the family Mustelidae for fur.

\section{MATERIALS AND METHODS}

Mordovia is located in the central part of the European part of Russia. The Republic of Mordovia is located in the center of the European part of Russia. Its outer borders are defined by geographical coordinates $42^{\circ} 11^{\prime}-46^{\circ} 45^{\prime} \mathrm{E}$ and $53^{\circ} 38^{\prime}-55^{\circ} 11^{\prime} \mathrm{N}$ (Figure 1). The maximum distance from west to east is $298 \mathrm{~km}$, and the distance from south to north is between 57 and $140 \mathrm{~km}$. The area of the Republic of Mordovia is $26200 \mathrm{~km}^{2}$. Peculiarities of the ecological and geographical zoning of Mordovia are associated with its location in the center of European Russia and the northwestern slopes of the Volga Upland. In the west of Mordovia, the Volga Upland reaches the Oka-Don Lowland (Andreychev and Boyarova 2020; Andreychev and Kiyaykina 2020; Andreychev et al. 2020). 



Figure 1. Location of geoecological regions in Mordovia, Russia (red oval: where animals were trapped). Note: red circle: Vadskiy region, yellow circle: Mokshinskiy region, grey circle: Moksha-Vadskiy region, blue circle: Yuzhniy region, brown circle: IssaSivinsko-Rudninskiy region, orange circle: Insarskiy region, purple circle: Prialatyrskiy region, green circle: Vostochniy region, pink circle: Yugo-vostochniy region, dark blue circle: Surskiy region, black circle: Menya-P'yanskiy region

The climate of the region is moderately continental, with pronounced seasons throughout the year. The average annual air temperature varies from 3.5 to $4.0{ }^{\circ} \mathrm{C}$. The average January temperature range is between -11.5 and $12.3{ }^{\circ} \mathrm{C}$. After that, the temperature declines to $-47{ }^{\circ} \mathrm{C}$ occur. The average July temperature range is between +18.9 and $+19.8^{\circ} \mathrm{C}$. Extreme summer temperature values reach $37{ }^{\circ} \mathrm{C}$. In Mordovia, the average annual precipitation is $480 \mathrm{~mm}$.

All eleven geoecological regions of Mordovia belong to three types of landscapes, the classification of Yamashkin (2001). These landscapes are defined by the differences in topography, slope, continental geological rocks, hydrography, and soils. Landscapes of broadleaf forests and forest-steppes of erosion-denudation plains include Yugo-Vostochniy, Vostochniy, and Insarskiy geoecological regions. The landscape is characterized by a strongly eroded elevated terrain, where the arc-shaped watershed of rivers Sura and Alatyr is distinguished. A typical feature of the terrain is the spread of steep slopes. Landscapes of broadleaf forests and forest-steppes of secondary morainic plains of the Volga upland include Menya-P'yanskiy, IssaSivinsky-Rudninsky, Moksha-Vadskiy, and Yuzhniy geoecological regions. A characteristic feature of this landscape is a well-defined slope change of natural territorial assemblage from watersheds to the valleys of medium-size rivers. Landscapes of mixed forests of waterglacial plains of the Oka-Don lowland and valleys of large rivers include Mokshinskiy, Vadskiy, Prialatyrskiy, and
Surskiy geoecological regions. Water-glacial plains are composed of sand with thin layers of loam. Groundwaters have a sporadic distribution. They are located at different depths. It causes a large mosaic in the degree of moisture content of natural assemblage. Features of the zonal position determine the presence of steppe and taiga elements here.

The material for this study was registered using route tracking and visual registration of carnivores, camera-trap surveys, and collecting dead animals in the Republic of Mordovia. The material was collected during expedition and stationary research in different districts of Mordovia in 2006-2021. During studies worked out 350 camera-traps / day, which is more than $8,000 \mathrm{~h}$ of observation. More than $1600 \mathrm{~km}$ of route track have been carried out, and 184 dead animals were found. Studies of the biology and ecology of mammalian species were carried out in different biogeocenoses. This is primarily a forest, meadow, swamp. In addition, we studied agricultural fields, gardens, settlements.

The carnivores species were identified using the classification of Kucheruk (1959) and Schwartz (1989) (Table 1). Latin names of species are given according to Wilson and Reeder (2005). Based on these studies, considering the ranges of carnivorous species, the representation of various faunal assemblages along the geoecological regions of Mordovia was determined. 
Table 1. The species composition of carnivorous in Mordovia, Russia, belonging to faunal assemblages

\begin{tabular}{|c|c|c|c|}
\hline \multirow[b]{2}{*}{ Taiga } & \multicolumn{3}{|c|}{ Faunal assemblage } \\
\hline & $\begin{array}{l}\text { Coniferous and broadleaf } \\
\text { forests }\end{array}$ & Steppe & $\begin{array}{l}\text { Widely distributed in several } \\
\text { natural areas }\end{array}$ \\
\hline $\begin{array}{l}\text { Ursus arctos (Linnaeus, } \\
\text { 1758), brown bear } \\
\text { Lynx lynx (Linnaeus, 1758), } \\
\text { Eurasian lynx }\end{array}$ & $\begin{array}{l}\text { Nyctereutes procyonoides (Gray, } \\
\text { 1834), raccoon dog } \\
\text { Martes foina (Erxleben, 1777), } \\
\text { stone marten } \\
\text { Martes martes (Linnaeus, 1758), } \\
\text { pine marten } \\
\text { Mustela lutreola (Linnaeus, } \\
\text { 1758), European mink } \\
\text { Mustela putorius (Linnaeus, } \\
\text { 1758), polecat } \\
\text { Neovison vison (Schreber, 1777), } \\
\text { American mink }\end{array}$ & $\begin{array}{l}\text { Mustela eversmanni (Lesson, } \\
\text { 1827), steppe polecat }\end{array}$ & $\begin{array}{l}\text { Canis lupus (Linnaeus, 1758), } \\
\text { wolf } \\
\text { Vulpes vulpes (Linnaeus, 1758), } \\
\text { red fox } \\
\text { Lutra lutra (Linnaeus, 1758), } \\
\text { otter } \\
\text { Mustela nivalis (Linnaeus, } \\
\text { 1766), weasel } \\
\text { Mustela erminea (Linnaeus, } \\
\text { 1758), stoat } \\
\text { Meles meles (Linnaeus, 1758), } \\
\text { European badger }\end{array}$ \\
\hline
\end{tabular}

\section{RESULTS AND DISCUSSION}

In Mordovia, 15 carnivorous species. The following number of registrations for each species was revealed: Ursus arctos (8), Canis lupus (49), Vulpes vulpes (1506), Lynx lynx (4), Nyctereutes procyonoides (15), Martes foina (24), M. martes (278), Mustela nivalis (350), M. erminea (92), M. lutreola (1), M. putorius (35), M. eversmanni (3), Neovison vison (176), Lutra lutra (22), Meles meles (98) were recorded. Of these, in the region, many species are found in coniferous and broad-leaved forests (40\%) and species widely distributed in several natural areas (40\%). The taiga type of fauna is represented by $13 \%$ of the total number of noted species. The steppe type of fauna is represented by only $7 \%$ of the total number of noted species (Figure 2). Thus, mammals from four different faunistic groups live in Mordovia. Two groups are predominant in terms of the number of species. The other two groups are several times inferior to them in terms of the number of species. This confirms that the region is transitional from one natural zone to another. Therefore, there is a high probability that new species will appear in it from two natural zones: the steppe and taiga. This circumstance concerns not only carnivorous mammals but also mammals from other orders.

In Insarskiy, Issa-Sivinsky-Rudninsky, and Yuzhniy geoecological regions, the analysis of the carnivorous species composition for belonging to the fauna types showed a considerable number of representatives of widespread in several natural zones of the faunal assemblage (57\%). Species of coniferous and broad-leaved forests (43\%) were less represented. The forest of Saransk has the lowest population density of the pine marten. For the forest zones of the Insarskiy region, the area of individual marten plots is from 2.4 to $3.2 \mathrm{~km} 2$. The marten prefers to inhabit remote forest biotopes with a large number of hollow trees. It is attracted to biotopes with an abundance of small rodents. But it can also stay in small forest belts. The marten avoids populated areas. It arranges its shelter in the hollows of trees, usually high above the ground (from 2 to $20 \mathrm{~m}$ and above). It often settles in the nests of magpies. There is usually no nest material in the hollows. Permanent shelters are also used as temporary shelters. The marten is active at dusk and night. Young animals are often found during the day. Martens are semiwoody mammals. But they feed mainly on the ground, and the squirrel pursues in the crowns of trees. Therefore, in the forests, the predator comes to the trees only in search of shelter. The red fox is most affected by stray dogs (Andreychev et al. 2015). In broods of fox, 3-6 puppies were recorded. The largest number of cases of found dead foxes for various reasons was noted in the second half of April. Most of them were torn to pieces by other animals. Foxes in these areas live in a wide variety of biotopes but prefer forests, clearings interspersed with agricultural land, meadows, swamps, and river valleys. Avoids dense forests. Mostly the fox settles in burrows located in ravines. Selfdug burrows usually have $3-5$, sometimes up to 15 , inlets. The nest chamber is lined with dry plants. It can also occupy the burrows of badgers and marmots. There are cases when the fox makes burrows near human settlements. Foxes' burrows are found at intervals of one burrow for every 1-4 km2. The diameter of the burrows at the entrance is $26-33 \mathrm{~cm}$. A large proportion of uninhabited burrows per 1 inhabited one (4: 1) was noted. Rodents, primarily gray voles, predominate in the fox's diet in the region. In search of prey, foxes periodically visit agricultural fields. The counts show that there are on average 8 feces and 37 urinary points per $10 \mathrm{~km}$. Most of the marking activity was noted in deciduous forests.

The Menya-P'yanskiy region is represented by two predominant species living in coniferous-deciduous forests $(50 \%)$ and widely distributed in several natural zones (33\%). The steppe fauna type contains $17 \%$ of species. Here, on the border with the Chuvashia, the steppe polecat is known. This is a rare species in the region. Steppe polecat lives in open habitats (fields, meadows, slopes). He avoids forests and human settlements. Leads predominantly to a solitary lifestyle but can form small populations. Its diet includes hamsters, ground squirrels, marmots, voles, mice, and other small animals in the region. The burrows of its victims widened by the animal serve as shelters. On rare occasions, he digs burrows on his own. 


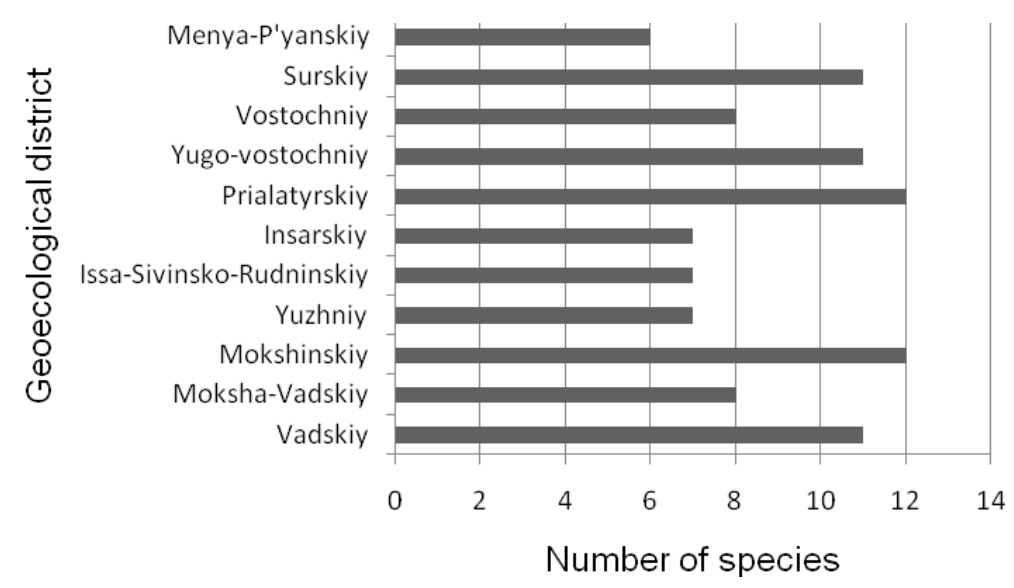

Figure 2. Number of carnivorous species in the geoecological regions of Mordovia, Russia

In Vostochniy geoecological region, we found an equal ratio of species groups widely distributed in several natural zones $(50 \%)$ and living in coniferous and broad-leaved forests $(50 \%)$. This circumstance is due to the poor variety of biological stations. Therefore, widespread species for Russia are noted here. The appearance of new species for this area is unlikely. An exception may be the migration path from other places where the habitat conditions are more diverse. Steppe and taiga species are not found here. One of the common inhabitants here is the American mink. The species inhabits all water bodies. American mink prefers to settle along rivers. On artificial reservoirs (ponds), footprints are often recorded along the banks. On a pond near the village of Tarasovo, it is often recorded visually. As a shelter, he uses burrows dug out by himself. Burrows have up to eight entrances. Where burrows are not observed, this species hides in cavities under the roots of trees. The American mink is lining the nesting chamber with dry grass, leaves, wool. The activity changes with the seasons. There is a lot of activity in the spring and summer. The predator hunts mainly in the evening hours. The length of the migration route per day ranges from several hundred meters to $1 \mathrm{~km}$. It all depends on the availability of food. The diet includes voles, molluscs, fish, crayfish, insects, and birds. In summer and autumn, terrestrial animals predominate in the composition of feed. One of the exciting mammals in this area is the stone marten. It is found in this area more than in other areas. This is due to the presence of large areas of open land. There is less competition with the pine marten. A white spot on the throat distinguishes this mammal. This patch bifurcates at its rear and reaches the base of the forelimbs. The tail is weaker than that of the pine marten. The muzzle before the eyes is colored lighter than the forelimbs. The stone marten is a typical inhabitant of shrubs and gardens. Often found in human buildings and old parks. She arranges shelters in stone houses, old magpie nests, hollows. The spherical nest is lined with dry grass, small twigs. The stone marten is active in the evening and at night. Small rodents, birds, insects dominate the diet. In summer and autumn, it often eats vegetable food (berries). In this region, the red fox is a frequent carrier of rabies (Boyarova et al. 2020).
The Vadskiy geoecological region is dominated by widespread species in several natural zones (55\%) and species of coniferous-deciduous forests $(27 \%)$. The taiga fauna type contains $18 \%$ of species. The badger is a common inhabitant of this forested area. There are many ravines here. The badger prefers to settle in them. Another essential condition for him is the presence of reservoirs. Lives in family groups. It leads to twilight and a nocturnal lifestyle. It digs intricate burrows with numerous entrances. In the underground shelter, nesting chambers and a toilet are allocated. The nest chamber is usually arranged a few meters from the inlet. Its width is always greater than its height. Badgers are found on the soil surface from March to October. In autumn, they get obese and plunge into long winter sleep. It eats invertebrates and small vertebrates. It often feeds on plant foods (fruits, berries, acorns, roots, and leaves). He is a voracious animal. It is beneficial as it destroys many forest and agricultural pests. Reproduction takes place in early spring or summer. The duration of pregnancy is between 270 and 376 days. On average, 2-3 cubs are born. The smallest distance between the nearest neighboring badger settlements is $2.2 \mathrm{~km}$. Another mammal typical of this area is the stoat. It inhabits river floodplains, floodplain forests, ravines, and wetlands. It leads to a solitary lifestyle. Adheres to a certain territory. It does not dig burrows on its own. He lives in the burrows of the rodents he killed. The burrow is lined with wool or dry foliage in the nesting chamber. It also settles under stumps, tree roots, in hollows. In winter, the shelters are located in the same biotopes as in summer. It is active mainly at night and dusk. In frosty weather with snowfall, it may not leave the shelter for several days. The area of an individual plot varies from 10 to 100 hectares, depending on its feeding capacity. Rodents from the basis of food. It also catches shrews, small birds, amphibians, and reptiles. Rarely eats fish and carrion. In summer, it eats insects and berries. It kills prey by biting through the occipital region of the skull. With an abundance of rodents, it kills them more than it can eat. Makes food supplies.

Regarding the faunal assemblage, the Yugo-Vostochniy region is represented by two predominant groups of species widely distributed in several natural zones (55\%) and living in coniferous-deciduous forests $(36 \%)$. The taiga fauna 
type contains $9 \%$ of species. In this region, the weasel is a frequent prey of the Eagle owl (Andreychev et al. 2014, 2016). Weasel is a common species in the region. It inhabits mainly agricultural lands. The main meetings are dated to meadows, fields, and settlements. Often settles near a person's dwelling. In the garden plots, cats caught weasels. In the forest, the animal is common on the edges. The weasel has no permanent refuge. She does not dig burrows on her own. For breeding and shelter, it uses the underground dwellings of voles. It also makes nests under old tree stumps. Temporary shelters are located under the roots of trees. The activity is year-round, mainly at night and twilight hours. But often, weasel occurs during the day. It leads to a solitary lifestyle. It keeps sedentary and can make long migrations only in hungry years. The size of the habitat depends on the abundance of food. Moves within 1$2 \mathrm{~km}$ per day. In winter, it leads to a predominantly snowy lifestyle and catches prey under the snow. It feeds on mouse-like rodents, mainly voles, and mice.

In Moksha-Vadskiy geoecological region, the dominants in terms of faunal types are species widely distributed in several natural zones (63\%). The second position is occupied by species preferring coniferous and broad-leaved forests $(37 \%)$. The polecat usually settles at the edge of the woods. It is often found on the outskirts of villages. He arranges shelters in human buildings, haystacks, in hollows under the roots, in heaps of brushwood, in hollows of trees. The nesting chamber has a spherical shape, $30-35 \mathrm{~cm}$ in diameter. It lines it with dry grass and wool. Shows activity at night. When there is little food, it can hunt during the day. It moves stealthily among bushes or under fallen trees. Climbs swim and dive well. It feeds on voles, shrews, amphibians, reptiles, birds, fish, insects, and plants.

The analysis of carnivorous species noted in the Mokshinskiy and Prialatyrskiy regions, belonging to the fauna types, showed their homogeneity. The highest number of species represented carnivorous of widespread species $(50 \%)$. The second position is occupied by species preferring coniferous and broad-leaved forests (33\%). Finally, the taiga fauna type contains $17 \%$ of species. The high species diversity of carnivorous (12 species) in this region is caused by an increased number of Protected Areas. A similar situation was observed with the faunas of rodents and insectivorous mammals (Andreychev 2020a,b). First of them is the Mordovia State Nature Reserve, where the following rare species are noted: European mink (Critically Endangered in IUCN Red List), brown bear (Endangered in Red Book of the Republic of Mordovia), Eurasian lynx (Endangered in Red Book of the Republic of Mordovia), European badger (Vulnerable in Red Book of the Republic of Mordovia), otter (Rare in Red Book of the Republic of Mordovia). In addition, the Mokshinskiy region has a high population density of amphibious carnivorous mammals, which is associated with the number of their prey (Andreychev 2017; Andreychev et al. 2019).

Concerning the faunal assemblage, the Surskiy region is represented by two predominant groups of species widely distributed in several natural zones $(55 \%)$ and living in coniferous-deciduous forests $(36 \%)$. The taiga fauna type contains $9 \%$ of species. This, Surskiy, riverine region, and Mokshinskiy, Prialatyrskiy region, also have a high species diversity. There are 11 species of carnivorous. Here, such rare and small-numbered species are noted: otter, European badger, Eurasian lynx, raccoon dog. The latter species is found here more often than in other regions. Most common in floodplain forests, in thickets of bushes along the banks of water bodies. She settles under a windbreak, among tall grasses, in abandoned burrows of badgers and foxes. The activity is predominantly twilight and nocturnal. As a rule, he lives sedentary. With a lack of food, it can make long migrations. In autumn, it becomes very fat and plunges into winter sleep. During the thaw period, it can wake up and wander in search of food. The raccoon dog is one of the main vectors of parasites and diseases, such as Echinococcus multilocularis, rabies, and Trichinella. Therefore, the distribution of this invasive alien species should be constantly monitored (Kauhala and Kowalczyk 2011). Otters in the region prefer rivers with clear, fast water and steep banks. The otter lives primarily solitary. Only females live with young ones. Animals rarely migrate due to changes in the food supply. Refugees are divided into permanent and temporary. It usually makes a permanent burrow under a steep bank. Root shelters serve as temporary shelters. Active at night. The length of an individual section along the river is usually up to $10 \mathrm{~km}$. The otter feeds mainly on fish, to a lesser extent on amphibians, mollusks, crustaceans, rodents, or waterfowl. The wolf is a permanent resident here. The howls of which were repeatedly recorded on digital voice recorders installed for recording owls (Andreychev et al. 2017; Lapshin et al. 2018) and recorded on the tracks. In the forest zone, the wolf prefers to keep along river valleys, clearings, forest edges. In the presence of reliable shelters, it settles near a person. Distribution and abundance depend on the availability of the leading food. Ungulates from the basis of food in the region. Cases of attacks on pets have been reported. With a lack of food, it eats amphibians, fish, giant insects; in times of famine - carrion. There have been cases of cannibalism.

Thus, our analysis of the proportions of faunal assemblages showed the highest representation of carnivorous in the geoecological regions of the landscape of mixed forests of the water-glacial plains of the Oka-Don lowland and the valleys of large rivers.

In discussing the results, it is of long-term plans to compare the distribution of the identified carnivorous species by faunal types in Mordovia with other regions of different natural zones, mainly, Saratov oblast, which belongs to the steppes of the European part of Russia. Eighteen carnivorous species have been recorded in this region (Shlyakhtin et al. 2008). The fauna of carnivorous mammals of the Saratov region is distinguished by a more significant number of steppe species in comparison with Mordovia. In addition, there are species in the Saratov region that are not found in Mordovia. This is a corsac fox (Vulpes corsac Linnaeus, 1768), marbled polecat (Vormela peregusna Güldenstadt, 1770), African wildcats (Felis silvestris lybica Forster, 1780), golden jackal (Canis aureus Linnaeus, 1758). 


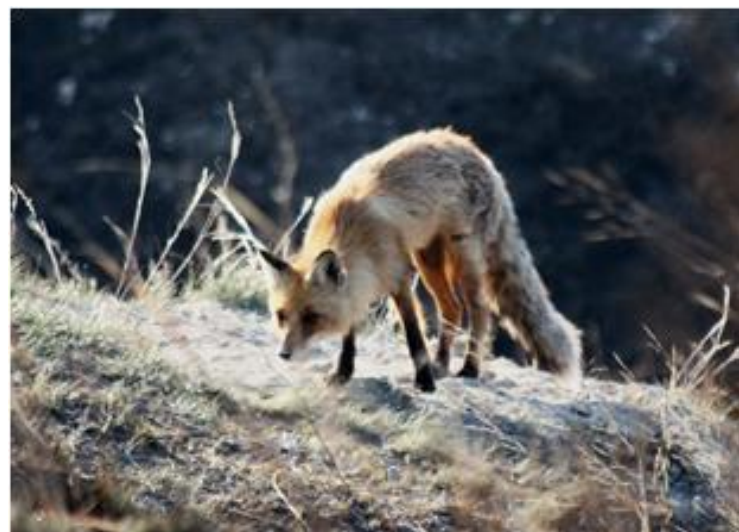

A

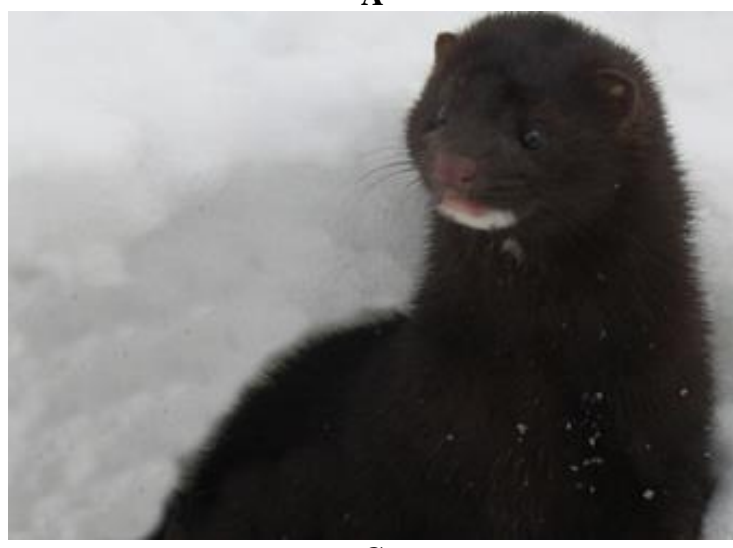

C

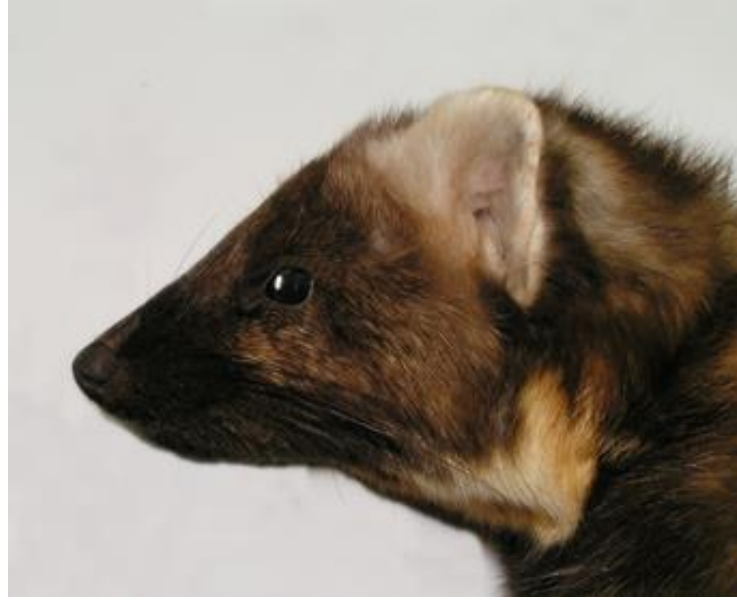

$\mathbf{E}$

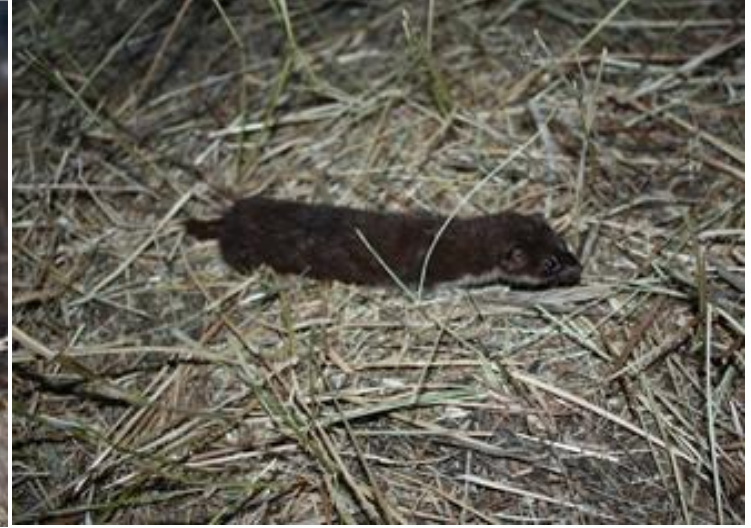

B



D

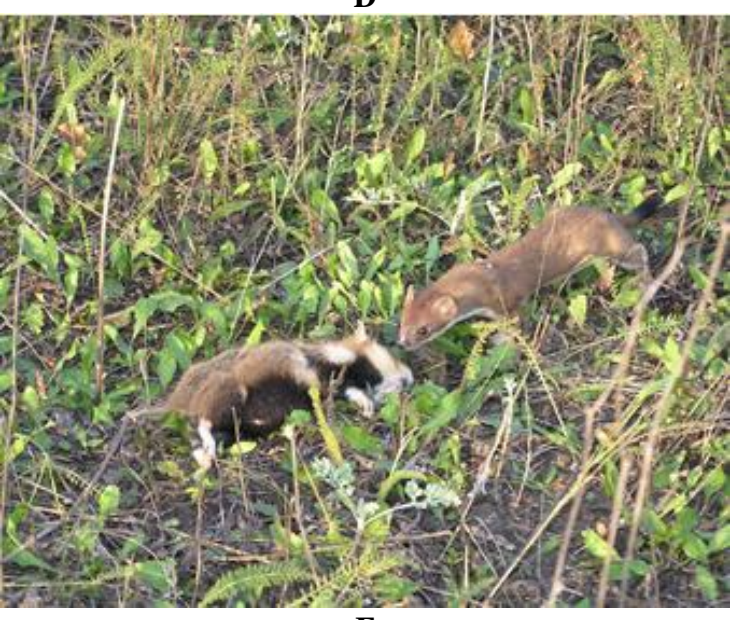

$\mathbf{F}$

Figure 3. Photo of carnivorous in Mordovia, Russia. A. Red fox (Vulpes vulpes); B. Weasel Mustela nivalis); C. American mink (Neovison vison); D. (Linnaeus, 1758), European badger (Meles meles); E. Pine marten (Martes martes); F. stoat (Mustela erminea) with prey (common hamster (Cricetus cricetus). (Photographs by A. Andreychev, M. Demidov and A. Lapshin)

We compared the carnivorous fauna in Mordovia with the Vladimir oblast belonging to the zone of coniferousbroad-leaved (mixed) forests. Fourteen carnivorous species have been recorded in this region (Kuzmin and Serbin 1998). Thus, this region is similar to Mordovia in terms of the predominance of two fauna types. The difference is due to the presence of stone marten in the fauna of Mordovia.

We compared the carnivorous fauna of Mordovia with Karelia belonging to the taiga. Fourteen carnivorous species have been recorded in this region (Ivanter 2008). The highest number of species belongs to two fauna types, including widespread in several natural zones (43\%) and inhabiting coniferous and broad-leaved forests $(36 \%)$. The taiga fauna type is represented by $21 \%$ of the total number of noted species. Karelia is also similar to Mordovia in terms of the predominance of two fauna types. However, a notable difference between the carnivorous fauna of Karelia is a high proportion of taiga species compared with Mordovia. A similar situation was observed with the fauna of rodents (Andreychev 2020b).

Thus, we want to emphasize the features distinguishing Mordovia by the proportion of different assemblages. 
Firstly, this is the uniqueness of this region, where both steppe and forest species are found. This is not related to many other areas. It is no coincidence that Mordovia is called a forest-steppe region. Second, it is a transitional zone between the steppe faunal assemblage and the faunal assemblage of coniferous and broadleaf forests.

In Mordovia, the proportion of carnivorous species of the total number of mammal species is $20 \%$. Carnivorous is somewhat inferior to rodents (37\%) (Andreychev 2020b; Andreychev and Kuznetsov 2020). Compared to West Java, Indonesia, Thailand, Mexico, the proportion of carnivorous species from other mammals is higher (Briceño-Méndez et al. 2017; Husodo et al. 2019; Sukmasuang et al. 2020; Clements et al. 2021). There are more species of carnivorous mammals in Brazil (26) than in Mordovia (Oliveira 2009). This is a differing feature Mordovia of many other mammal faunas, where representatives of the other animal orders predominate (Wirdateti et al. 2013; Sulistyadi 2016; Medina et al. 2018). We assume that the geographic latitude of the area inhabited by carnivorous species may be decisive in this difference. Climatic conditions exert real influence. Our research covers the northern sections $\left(\mathrm{ca} .54^{\circ} \mathrm{N}\right)$. Thus, the possible causes for the higher proportion of carnivores in Mordovia are more diverse forest-steppe living conditions.

\section{ACKNOWLEDGMENTS}

I am grateful to A. Lapshin, V. Kuznetsov, M. Demidov, V. Demidov, A. Zhalilov, G. Shkolov, V. Boriskin, A. Karmaikin, and M. Alpeev for support in carrying out field studies.

\section{REFERENCES}

Andreychev A. 2017. Population density of the Eurasian beaver (Castor fiber L.) (Castoridae, Rodentia) in the Middle Volga of Russia. For Stud 67: 109-115. DOI: 10.1515/fsmu-2017-0016

Andreychev A. 2020a. Ecological and faunal complexes of insectivorous mammals of the Republic of Mordovia, Russia. Biodiversitas 21(7): 3344-3349. DOI: 10.13057/biodiv/d210758

Andreychev A. 2020b. Proportion faunal assemblage of rodents in geoecological districts of Mordovia, Russia. Biodiversitas 21(9): 3961-3968. DOI: 10.13057/biodiv/d210906

Andreychev A, Boyarova E. 2020. Forest dormouse (Dryomys nitedula, Rodentia, Gliridae) - a highly contagious rodent in relation to zoonotic diseases. Forestry Ideas 26(1): 262-269.

Andreychev AV, Kiyaykina OS. 2020. Homing of the forest dormouse (Dryomys nitedula, Rodentia, Gliridae). Zool Zhurnal 99(6): 240-250. DOI: $10.31857 /$ S0044513420060033

Andreychev A, Kuznetsov V. 2012. Mammals of Mordovia. Mordovia State University, Saransk. [Russian]

Andreychev A, Kuznetsov V. 2020. Checklist of rodents and insectivores of the Mordovia, Russia. ZooKeys 1004: 129-139. DOI: 10.3897/zookeys.1004.57359

Andreychev AV, Kuznetsov VA, Alpeev MA. 2015. Daily activity rhythms of the red fox (Vulpes vulpes) in reproduction period of forest zone in Saransk city, Russia. Austrian J Tech Nat Sci 1(11): 69.

Andreychev A, Kuznetsov V, Lapshin A. 2019. Distribution and population density of the Russian desman (Desmana moschata L., Talpidae, Insectivora) in the Middle Volga of Russia. For Stud 71(1): 48-68. DOI: 10.2478/fsmu-2019-0012
Andreychev A, Kuznetsov V, Lapshin A, Alpeev M. 2020. Activity of the Russian desman Desmana moschata (Talpidae, Insectivora) in its burrow. Therya 11(2): 161-167. DOI: 10.12933/therya-20-801

Andreychev AV, Lapshin AS, Kuznetsov VA. 2014. Food spectrum of the Eagle owl (Bubo bubo) in the Republic of Mordovia. Zool Zhurnal 93(2): 248-258. DOI: 10.7868/S0044513414020032

Andreychev AV, Lapshin AS, Kuznetsov VA. 2016. Breeding success of the Eurasian Eagle-owl (Bubo bubo) and rodent population dynamics. Biol Bull 43(8): 851-861. DOI: 10.1134/S1062359016080045

Andreychev AV, Lapshin, AS, Kuznetsov VA. 2017. Techniques for recording the Eagle owl (Bubo bubo) based on vocal activity. Zool Zhurnal 96(5): 601-605. DOI: 10.7868/S004451341705004X

Bogdanov MN. 1871. Birds and animals of the black earth zone of the Volga region and the valley of the Middle and Lower Volga. Proceedings of the Society of Naturalists at Kazan University 1: 229. [Russian].

Boyarova E, Andreychev A, Kozlova I, Kuznetsov V. 2020. Red fox (Vulpes vulpes) as the main vector of animal's rabies in the foreststeppe zone of Republic of Mordovia. For Ideas 26(2): 355-365.

Briceño-Méndez M, Naranjo E, Pérez-Irineo G, Contreras-Perera Y, Sandoval-Serés E, Hidalgo-Mihart MG. 2017. Richness and trophic guilds of carnivorous mammals in ejido Nuevo Becal, Calakmul, Campeche, Mexico. Therya 8(2): 145-150. DOI: 10.12933/therya-17472

Charaspet K, Sukmasuang R, Khoewsree N, Pla-ard M, Paansri P, Keawdee B, Chanachai Y, Bhumpakphan N. 2021. Spatial and temporal overlaps of top predators: Dhole, tiger and leopard, and their potential preys in Huai Kha Khaeng Wildlife Sanctuary, Thailand. Biodiversitas 22(2): 580-592. DOI: 10.13057/biodiv/d220209

Clements GR, Rostro-García S, Kamler JF, Liang SH, Hashim AKBA. 2021. Conservation status of large mammals in protected and logged forests of the greater Taman Negara Landscape, Peninsular Malaysia. Biodiversitas 22(1): 272-277. DOI: 10.13057/biodiv/d220133

Husodo T, Febrianto P, Megantara EN, Shanida SS, Pujianto MP. 2019. Diversity of mammals in forest patches of Cisokan, Cianjur, West Java, Indonesia. Biodiversitas 20(5): 1281-1288. DOI: 10.13057/biodiv/d200709

Ivanter EV. 2008. Mammals of Karelia. Peter GU Publishing house, Petrozavodsk. [Russian]

Kauhala K, Kowalczyk R. 2011. Invasion of the raccoon dog Nyctereutes procyonoides in Europe: History of colonization, features behind its success, and threats to native fauna. Curr Zool 57(5): 584-598. DOI: 10.1093/czoolo/57.5.584

Kucheruk VV. 1959. Steppe faunistic complex of mammals and its place in the Palearctic fauna. Geography of the population of land animals and methods of its study. Publishing house of the USSR Academy of Sciences, Moscow. [Russian].

Kuzmin LL, Serbin VA. 1998. Catalog of Vertebrates of the Vladimir region. Vladimir. [Russian]

Lapshin AS, Andreychev AV, Kuznetsov VA. 2018. Daily and seasonal dynamics of the vocalization of the Eagle Owl (Bubo bubo, Strigiformes, Strigidae) in the central Volga region. Zool Zhurnal 97(1): 77-88. DOI: 10.7868/S0044513418010075

Lucherini M, Reppucci JI, Walker RS, Villalba ML, Wurstten A, Gallardo G, Iriarte A, Villalobos R, Perovic P. 2009. Activity pattern segregation of carnivores in the high Andes. J Mammal 90(6): 14041409. DOI: 10.1644/09-MAMM-A-002R.1

Medina CE, Díaz DR, Malaga BA, Medina YK, López E. 2018. Second record of Eumops chiribaya (Chiroptera, Molossidae) in Peru. Biodiversitas 19(6): 1979-1984. DOI: 10.13057/biodiv/d190601

Oliveira T D. 2009. Notes on the distribution, status, and research priorities of little-known small carnivores in Brazil. Small Carniv Conserv 41: 22-24.

Shlyakhtin GV, Zavyalov EV, Yakushev NN, Tabachishin VG, Anikin VV, Berezutsky MA, Koshkin VA. 2008. Biodiversity and Nature Protection in the Saratov Region. Saratov. [Russian].

Schwartz EA. 1989. Formation of small rodent and insectivorous fauna of taiga Eurasia. Fauna and ecology of rodents. Moscow. 17: 115-143. [Russian].

Stroud JT, Bush MR, Ladd MC, Nowicki R J, Shantz AA, Sweatman J. 2015. Is a community still a community? Reviewing definitions of key terms in community ecology. Ecol Evol 5(21): 4757-4765. DOI: 10.1002/ece3.1651

Sukmasuang R, Charaspet K, Panganta T, Pla-ard M, Khioesree N, Thongbanthum J. 2020. Diversity, abundance, activity period, and factors affecting the appearance of wildlife around the corridors 
between Khao Yai-Thap Lan National Parks, Thailand by camera trapping. Biodiversitas 21(5): 2310-2321. DOI 10.13057/biodiv/d210563

Sulistyadi E. 2016. Characteristics of large mammals community in Bali Barat National Park (BBNP). Zoo Indon 25 (2): 142-159.

Wilson DE, Reeder DM. 2005. Mammal Species of the World, Third Edition. The Johns Hopkins University Press. [US]
Wirdateti, Yulianto, Semiadi G. 2013. Distribution and habitat of Sunda pangolin (Manis javanica Desmarest, 1822) in the districts of Tanggamus and West Lampung, Lampung Province. Pros Sem Nas Masy Biodiv Indon 2: 181-186. [Indonesian]

Yamashkin AA. 2001. Geoecological analysis of the process of economic development of landscapes of Mordovia. Publisher of the Mordovia State University, Saransk. [Russian] 